\title{
МЕТОДОЛОГІЧНІ ПІДГРУНТЯ ІДЕНТИФІКАЦЇ̈ ДЕСКРИПТОРІВ ТА КОНТУРІВ УПРАВЛІННЯ СОЦІАЛЬНО-ЕКОНОМІЧНИХ СИСТЕМ
}

\author{
DOI: $10.32620 /$ cher.2021.4.13
}

Постановка проблеми. Використання системного підходу до управління соціально-економічними процесами пов'язано з існуванням іманентного протиріччя, обумовленого високим рівнем абстракції дефініції «система» та значним рівнем конкретності реальних економічних завдань. Зазначене потребує формалізації дескрипторів соціально-економічних систем та ідентифікації базових контурів управління. Метою статті є обгрунтована необхідність використання системного підходу до побудови конструкту соціально-економічної системи на підгрунті ідентифікації відповідних дескрипторів та контурів управління. Методологічною основою дослідження стало поєднання в межах системної парадигми напрацювань марксистської школи політичної економії, сучасного економічного мейнстріму та неортодоксальних течій. Основною гіпотезою дослідження стало припущення щодо можливості та доцільності використання дескриптивної методології ідентифікації систем до потреб управління соціально-економічними системами. $\mathrm{Bu}$ клад основного матеріалу. На підставі проведеного аналізу забезпечене певне підгрунтя для формування співвідношень відповідності дескрипторів національної соціально-економічної системи відповідним аксіоматичним умовам та базовим компонентам. Доведено, що дуалістичне розуміння людини як економічного та інституційного базового елементу соціально-економічної системи $є$ цілком доцільним до розуміння сутності національної економки. Інститути слід розглядати як структуру зв'язків, що поєднують елементи у єдину цілісність. . Доведено, що держава та її інститути відіграють діалектичну роль у забезпеченні цілісного існування національної соціально-економічної системи ринкового типу. Оригінальність та практична значущість дослідження. Отриманий теоретико-методологічний концепт має теоретичну значущість та може бути трансформований у відповідний інструментарій розробки науково-практичних рекомендацій 3 управління соціально-економічними системами. Висновки та перспективи подальших досліджень. Результати узагальнення теоретичних положень щодо сутності та змісту дефініцій «соціально-економічна система» та «національна економіка» обумовили висновок щодо неможливості розгляду економічної підсистеми (національної економіки) окремо від інших підсистем. Доведена доцільності та достатність використання дефініції «національна соціально-економічна система» як більш придатної для розв'язання діалектичної єдності соціальної та економічної підсистем суспільства. Подальші дослідження будуть спрямовані на розробку методичного забезпечення ідентифікації контурів управління на основі соціально-економічних дескрипторів.

\section{Ключові слова:}

система, системний дескриптор, контур управління, національна соціально-економічна система, територіальна локальність.

${ }^{1}$ Бурлуцька Світлана Владиславівна, д-р екон. наук, доцент, професор кафери економіки праці та менеджменту, Національний університет харчових технологій, м. Київ, Україна.

Burlutska Svitlana, Doctor Sciences in Economic, Associate Professor, Professor of Labour Economics and Management Department, National university of food technologies, Kyiv, Ukraine.

ORCID ID: 0000-0002-9497-7917

e-mail: lanavb75@gmail.com

${ }^{2}$ Бурлуцький Сергій Віталійович, д-р екон. наук, доцент, координатор $з$ питань моніторингу, оцінки та навчання Департаменту моніторингу, оцінки та навчання, USAID Democratic Governance East Activity, м. Київ, Україна.

Burlutski Sergii, Doctor Sciences in Economic, Associate Professor, Monitoring, Evaluation and Learning Coordinator of the Monitoring, Evaluation and Learning Department, USAID Democratic Governance East Activity, Kyiv, Ukraine.

ORCID ID: 0000-0003-0157-2564

e-mail: magistrdr@gmail.com 


\section{METHODOLOGICAL BASIS OF THE DESCRIPTORS IDENTIFICATION AND CONTROL CIRCUITS OF SOCIO-ECONOMIC SYSTEMS}

Statement of the problem. Use of the system approach to management of social and economic processes is connected with existence of the immanent contradiction caused by a high level of abstraction of the definition "system" and a considerable level of concreteness of real economic tasks. The mentioned thesis needs formalization of descriptors of socio-economic systems and identification of basic management contours. The purpose of the article is to substantiate the necessity of using a systematic approach to the construction of the socio-economic system construct based on the identification of relevant descriptors and management contours. The methodological basis of the study was a combination of the Marxist school of political economy, the modern economic mainstream and unorthodox currents within the systemic paradigm. The main hypothesis of the study was the assumption regarding the possibility and feasibility of using descriptive methodology of systems identification to the needs of management of socio-economic systems. Statement of the basic material. On the basis of the analysis, a certain basis is provided for the formation of correlations of correspondence of the descriptors of the national socio-economic system to the corresponding axiomatic conditions and basic components. It is proved that the dualistic understanding of the individual as an economic and institutional basic element of the socio-economic system is fully appropriate to the understanding of the essence of the national economy. Institutions should be seen as a structure of connections that combine the elements into a unified integrity. It is proved that the state and its institutions play a dialectical role in ensuring the integral existence of the national socio-economic system of market type. Originality and practical significance of the research. The resulting theoretical and methodological concept has theoretical significance and can be transformed into relevant tools for the development of scientific and practical recommendations on the management of socio-economic systems. Conclusions and prospects for further research. The results of generalization of theoretical statements on the essence and content of the definitions of "socio-economic system" and "national economy" led to the conclusion about the impossibility of considering the economic subsystem (national economy) separately from other subsystems. The expediency and sufficiency of the use of the definition "national socio-economic system" as more acceptable for solving the dialectical unity of social and economic subsystems of society was proved. Further research will focus on the development of the methodical support for the identification of management contours on the basis of socio-economic descriptors.

Key words:

system, system descriptor, management outline, national socio-economic system, territorial locality.

\section{МЕТОДОЛОГИЧЕСКИЙ БАЗИС ИДЕНТИФИКАЦИИ ДЕСКРИПТОРОВ И КОНТУРОВ УПРАВЛЕНИЯ СОЦИАЛЬНО-ЭКОНОМИЧЕСКИХ СИСТЕМ}

Постановка проблемы. Использование системного подхода к управлению социально-экономическими процессами связано с существованием имманентного противоречия, обусловленного высоким уровнем абстракции дефиниции "система" и значительным уровнем конкретности реальных экономических заданий. Отмеченный тезис нуждается в формализации дескрипторов социально-экономических систем и идентификации базовых контуров управления. Целью статьи является обоснованная необходимость использования системного подхода к построению конструкта социально-экономической системы на основе идентификации соответствующих дескрипторов и контуров управления. Методологической основой исследования стало сочетание в пределах системной парадигмы наработок марксистской школы политической экономии, современного экономического мейнстрима и неортодоксальных течений. Основной гипотезой исследования стало предположение относительно возможности и целесообразности использования дескриптивной методологии идентификации систем к потребностям управления социально-экономическими системами. Изложение основного материала. На основании проведенного анализа обеспечен определенный базис для формирования соотношений соответствия дескрипторов национальной социально-экономической системы соответствующим аксиоматическим условиям и базовым компонентам. Доказано, что дуалистическое понимание человека как экономического и институционного базового элемента социально-экономической системы является полностью целесообразным к пониманию сущности национальной экономки. Институты следует рассматривать как структуру связей, которые сочетают элементы в единую целостность. Доказано, что государство и его институты играют диалектическую роль в обеспечении целостного существования национальной социально-экономической системы рыночного типа. Оригинальность и практи- 
ческая значимость исследования. Полученный теоретико-методологический концепт имеет теоретическую значимость и может быть трансформирован в соответствующий инструментарий разработки научно-практических рекомендаций по управлению социально-экономическими системами. $B b l в о д b l$ и перспективы дальнейших исследований. Результаты обобщения теоретических положений относительно сущности и содержания дефиниций "социально-экономическая система" и "национальная экономика" обусловили вывод относительно невозможности рассмотрения экономической подсистемы (национальной экономики) отдельно от других подсистем. Доказана целесообразность и достаточность использования дефиниции "национальная социально-экономическая система" как более приемлемой для решения диалектического единства социальной и экономической подсистем общества. Дальнейшие исследования будут направлены на разработку методического обеспечения идентификации контуров управления на основе социально-экономических дескрипторов.

\section{Ключевые слова:}

система, системный дескриптор, контур управления, национальная социально-экономическая система, территориальная локальность.

Постановка проблеми. Результатом проведеного методологічного пошуку, відображеного в наших попередніх роботах $[1,2]$, стало обгрунтування доцільності використання дескриптивного гносеологічного визначення систем. Отже, система ідентифікувалась як здатна до саморозвитку цілісність, утворена достатньою сукупністю елементів, здатних до самовідтворення й відносно самостійного функціонування, та поєднаних мережею істотних структурних, генетичних та субординаціних зв'язків. В якості базового методологічного конструкта використовувалося шість базових компонентів: A1 - характеристика вихідних утворень (елементів, складових); А2 - характеристика сполучень вихідних утворень; $\alpha-$ фіксація відносин та зв'язків між вихідними утвореннями; $\beta 1$ - характеристика отриманого утворення; $\beta 2$ - фіксація функціонування отриманого утворення; $\gamma$ - наявність додаткових характеристик. Перші п'ять перелічених компонентів ідентифікують систему через тріаду «елементи - зв'язки - цілісність», а компонент «ү» забезпечує конкретизацію дефініції та створює підгрунтя для визначення певних класів систем [1].

Разом $з$ тим, слід зазначити, що використання системного підходу до управління саме соціально-економічними процесами не $є$ ідеальним. Це пов'язано з іманентним протиріччям, обумовленим високим рівнем абстракції дефініції «система», з одного боку, та значним рівнем конкретності реальних економічних завдань, розв'язання яких передбачається шляхом системної теорії, з другого боку. Зазначене обумовлює необхідність подальшого методологічного аналізу з метою формалізації дескрипторів соціально-економічних систем та ідентифікації базових контурів управління.
Аналіз останніх досліджень та публікацій. Перші комплексні наробки саме 3 системного уявлення функціонування суспільства (соціально-економічних систем) належать марксистській течії економічної науки. В дослідженнях К. Маркса та Ф. Енгельса була зроблена вдала спроба узагальнення закономірностей дослідження та пізнання цілісних об’ єктів. В наш час у соціально-економічному контексті проблема системного дослідження отримала визначальний поштовх після розробки «системної парадигми» Я. Корнаї [3] та концепції сферного підходу до розуміння соціально-економічних систем радянського філософа Л. Семашко [4]. Сучасний економічний мейнстрім (Г. Башнянин, А. Алієва, В. Весніна та С. Воловікова) також активно використовує термін «соціально-економічна система» [5]. Результати аналізу публікацій 3 даної тематики свідчать про значні наробки, але переважно в межах навчальних посібників та підручників. Нечисленні публікації наукового спрямування мають несистемний характер.

Метою статті с обгрунтована необхідність використання системного підходу до побудови конструкту соціально-економічної системи на підгрунті ідентифікації відповідних дескрипторів та контурів управління.

Виклад основного матеріалу дос-лідження. Сучасний економічний мейнстрім активно використовує термін «соціально-економічна система» та, в залежності від ступеню відокремлення системи 3 оточуючого середовища, передбачає економічний або соціальний підхід. Вважаємо, що безпосереднє формування абстрактного визначення соціальноекономічної системи є недоцільним (ні шляхом визначення найбільш адекватного тракту- 
вання, ні шляхом синтезу). Важливим є ідентифікація якісних та кількісних характеристик системи, а отже не параметрів єдності, а суттєвих відмінностей. Разом з тим, вважаємо за доцільне сконцентрувати увагу саме на системному баченні соціально-економічних процесів, системних концептуальних схемах та зразках розв'язання задач.

Діалектика сформованого завдання полягає у сутності самого системного аналізу. Системні настанови (загальність теорії систем) обумовлює необхідність ідентифікації універсальних властивостей, закономірностей розвитку соціально-економічних систем. Таке абстрагування призводить до природнього виключення з аналізу національних економічних та позаекономічних особливостей, притаманних окремим господарським системам. Навіть якщо це системи одного класу (наприклад, трансформаційні економіки) їх розвиток не $\epsilon$ i не може бути однаковим. 3 іншого боку зв'язка «цілісність-обмеженість» соціальноекономічної системи передбачає наявність відмінностей, що дозволяють відокремити конкретну систему з загального світового господарства. Отже, врахування специфічності, національної завантаженості об'єкту нашого дослідження $є$ обов'язковою та необхідною умовою як в методологічному, так і в прикладному аспектах. Цей висновок споріднений 3 тезою професора Ю. Ольсевича «національний чинник не єдиний $з$ детермінуючих чинників, але якщо теорії чимось розрізняються або співпадають, то це обумовлено різницею або збігом національних економічних інтересів» [6]. Таким чином, логічним $\epsilon$ аналіз національних соціально-економічних систем, національного господарства, національної економіки. Відповідно до розглянутих раніш системних компонентів фокус дослідження зміщується на національну конкретизацію дефініції (компонент «үү»).

Наявні напрацювання вітчизняних та закордонних фахівців у сфері дослідження національних соціально-економічних систем носять дещо розрізнений характер. Перш за все, це стосується розуміння об'єкту проблеми. Результати аналізу публікацій 3 даної тематики свідчать про значні наробки, але переважно в межах навчальних посібників та підручників. Нечисленні публікації наукового спрямування мають несистемний характер. Так, у статті професорів А. Алієва, В. Весніна та С. Воловікова «Системність національної економіки та задачі iï регулювання» відсутнє пряме визначення терміну «національної економіки», але міститься характеристика компонентів національної економіки - економічної підсистеми, правової, соціальної та природноекологічної складових [7]. Така точка зору $є$ цілком неприйнятною. Національна економіка - це економіка обмежена певними національними межами, а соціальна підсистема не тільки не може бути складовою економіки, а $є$, 3 нашої точки зору, системою більш високого рівня. За своїм змістом дорівнюються дефініції «національна економіка», «економічна система» та «народне господарство»у роботі Ю. Іоди. Авторка наполягає на розумінні національної економіки як державно оформленому соціально-економічному утворенні, між суб' сктами якого переважним засобом зв'язку виступає ринок [8]. В даному випадку має місце вже загадана методологічна помилка, до того ж, єдиною детермінантною взаємозв'язків між суб' єктами виступає тільки ринок, що набагато звужує розуміння змісту соціальноекономічних звязків.

Професор Г. Залозна у своєму дослідженні використовує термін національно-державна економічна система: історично сформована в певних територіальних межах специфічна сукупність взаємодіючих та взаємозалежних елементів, локальність яких по відношенню до загального економічного середовища забезпечується відповідними державними інститутами [9]. На схожому розумінні національної економіки як механізму забезпечення відтворення економічних систем в межах державних утворень наполягає і завідувач лабораторією ЦЕМІ РАН професор В. Дементьев [10]. Якщо провести декомпозицію останніх двох визначень, то цілком логічне відокремлення двох складових: економічна система та держава. Вже на цьому етапі зрозумілі помилки методологічного плану. Держава як інститут політичної системи, що має верховну владу над усім суспільством, $є$ результатом історичного розвитку суспільних відносин (продуктом соціальної еволюції). Це є логічним висновком майже 3 усіх теорій виникнення держави (за виключенням теологічної). Отже, обмеження всього комплексу взаємодій тільки компонентами держави та економічної підсистеми ігнорує наявність суспільства 3 притаманною йому сукупністю соціальних відносин.

Більшою послідовністю та системністю $\epsilon$ визначення національної економіки запропоноване колективом авторів під керівництвом 
професора В. Тарасевича «національна економіка являє діалектичну єдність взаємопов'язаних та взаємодіючих економічних суб'єктів, секторів та укладів... $є$ елементом ноосфери надскладної людинорозмірної системи універсумного типу як суперечливої єдності людини і природи» [11]. Разом з тим, в цьому визначенні існує протиріччя 3 аксіоматичною умовою «єдине», а саме суб'єкти, сектори та уклади не є однопорядковими елементами. До того ж, компонент «ү» (а це складова дефініції «національна») не має чіткої ідентифікації. Схожі проблеми містить визначення, запропоноване професором В. Решетило: «національна економіка - це єдина економічна система суспільства, в якій стабільними, динамічними, повторюваними й стійкими взаємозв'язками поєднані умови та фактори виробництва, його результати; це сукупність економічних агентів і економічних відносин, інститути, традиції, принципи та механізми господарювання, що у своїй взаємодії формують єдиний господарський механізм нації» [12]. У цьому трактуванні, по-перше, логічна та змістовна надлишковість притаманна термінам, що характеризують властивості системних взаємозв'язків: стабільність, повторюваність, стійкість. По-друге, до елементів складових системи віднесено різнорідні компоненти - економічні агенти, умови, фактори виробництва, що не відповідає настановам системного аналізу. По-трете, категорія «механізм господарювання» за обсягом свого поняття значно більша ніж національна економіка. Господарчий механізм існує в межах певного історичного оточення, національних особливостей відтворення суспільства з усією сукупністю не тільки економічних, але й соціальних взаємозв' язків.

Можна впевнено констатувати, що у більшості проаналізованих визначень національної економіки об'єктом є не економічна підсистема, а господарство як воно є. Основний висновок проведеного аналізу полягає у неможливості розгляду економічної підсистеми (національної економіки) не залежно від інших підсистем. Будь-які спроби це зробити призводять або до вихолощення змісту, або до протирічь системного характеру. Використання терміну національна економіка (принаймні у існуючому у широкого загалу розумінні) є некоректним.

Дуалізм розвитку соціально-економічної системи знаходить своє логічне пояснення у працях К. Поланьї «жодне суспільство не може обходитися без системи, спрямованої на забезпечення порядку у сфері виробництва та розподілу благ... це не обумовлює існування самостійних економічних інститутів незалежних від інститутів соціальних: економічний порядок звичайно є функцією від соціального, причому другий забезпечує перший» [13].Обмеженість економічної системи, спрямованої на задоволення потреб виключно економічними благами, обумовлена ії неспроможністю до створення позаекономічних благ. Існування економічної системи без соціальної неможливо, як і навпаки.

Результати аналізу напрацювань представників різноманітних наукових шкіл (від класиків до сучасного «мейнстируму» та неортодоксальних течій) призводить до логічного висновку про примат розуміння людини як базового елементу соціально-економічної системи. Разом з тим, у економічних дослідження чітко позначені дві кардинально протилежні позиції щодо принципів функціонування людини. Відповідно до першої позиції, основним елементом $є$ індивід 3 його потребами (методологія індивідуалізму) і загальний стан системи, обумовлений функціонуванням та настановами такої «економічної людини». За другою (більш системною на наш погляд) функціонування людини обумовлюється системою, іiі інтегративними властивостями та законами композиції. Ця неортодоксальна позиція передбачає, що функціонування людини детерміновано не егоїстичними, а соціальними коренями поведінки, пріоритетами кооперації та співпраці.

Професор НДУ ВШЕ В. Автономов (як представник мейнстриму) наполягає, що однією 3 важливіших підвалин сучасної науки $є$ саме «економічна людина» - необхідна епістомологічна абстракція та модель, максимально наближена до реальної людської поведінки [14]. 3 точки зору представників інституціональної течії, постулат «економічної людини» $є$ абстракцією, а отже, не розкриває інституційного підгрунтя суспільного функціонування, не враховує чинник обмеженої раціональності. Ця модель $є$ тільки непереконливою формалізацією. Реальна людина $є$ продуктом попередніх поколінь, національної спадщини у формі інстинктів, звичок та соціальних концепцій. Моделі «економічної людини» протиставляється концепт «людини інституційної». Як зазначається у дослідженні «Homo institutius - Людина інституційна» ця 
теоретична конструкція виникає коли нераціональний, повністю обмежений визначеною йому зовні роллю агент протиставляється повністю раціональному, ізольованому від соціального оточення та спрямованому на максимізацію корисності індивіду [15].

На нашу думку, наведені вище концепції «людини економічної» та «людини інституціональної» незважаючи на формальне протиріччя $є$ діалектичною єдністю одного і того суб'єкта. Економічні настанови передбачають раціональність поведінки, здатність до мінімізації витрат та максимізації добробуту. Настанови інституціональні, навпаки, обумовлюють підлеглість людини формальним та неформальним нормам, настановам світогляду та моралі.

Результати проведеного аналізу забезпечують певне підгрунтя для формування співвідношень відповідності дескрипторів націо- нальної соціально-економічної системи відповідним аксіоматичним умовам та базовим компонентам (табл. 1).

Отже, дуалістичне розуміння людини як економічного та інституційного базового елементу соціально-економічної системи $є$ цілком доцільним та придатним до розуміння сутності національної економки. Інститути, у свою чергу, слід розглядати як структуру зв'язків, що поєднують елементи у єдину цілісність. До такого розуміння соціально-економічної системи досить близька теорія господарського порядку В. Ойкена.

Територіальна локальність простору сталої взаємодії економічних агентів (превалювання національного над глобальним) $\epsilon$ саме тим якісним індикатором, що в нашому випадку конкретизує загальну дефініцію «соціально-економічна система» до рівня національної економіки.

\section{Таблиця 1 - Відповідність дескрипторів національної соціально-економічної системи аксіоматичним умовам}

\begin{tabular}{|c|c|c|}
\hline $\begin{array}{c}\text { Аксіоматичні } \\
\text { умови системності }\end{array}$ & $\begin{array}{c}\text { Базові } \\
\text { системні } \\
\text { компоненти } \\
\end{array}$ & $\begin{array}{c}\text { Дескриптори національної соціально-економічної системи } \\
\text { (національної економіки) }\end{array}$ \\
\hline Множина об’єктів & \multirow{3}{*}{$\mathrm{A} 1, \mathrm{~A} 2$} & \multirow{2}{*}{$\begin{array}{l}\text { достатня кількість економічних агентів, спроможних до са- } \\
\text { мовідтворення та відносно самостійного функціонування, } \\
\text { й детермінованих інституційними законами композиції }\end{array}$} \\
\hline Достатність & & \\
\hline Єдине & & $\begin{array}{l}\text { генетична однорідність та спрямованість функціонування } \\
\text { на корисний результат }\end{array}$ \\
\hline Єдність & $\alpha$ & $\begin{array}{l}\text { інституційна архітектоніка (інституційна матриця) як суку- } \\
\text { пність формальних та неформальних правил (законів) ком- } \\
\text { позиції }\end{array}$ \\
\hline \multirow{3}{*}{ Існування } & $\beta 1$ & $\begin{array}{l}\text { цілісність як здатність до самовідтворення об’єктного } \\
\text { складу системи та структури звязків }\end{array}$ \\
\hline & $\beta 2$ & $\begin{array}{l}\text { упорядковане функціонування та безпека обумовлена існу- } \\
\text { ванням держави як форми політичної організації суспіль-- } \\
\text { тва }\end{array}$ \\
\hline & $\gamma$ & $\begin{array}{l}\text { - територіальна локальність простору сталої взаємодії } \\
\text { економічних агентів (превалювання національного над } \\
\text { глобальним); } \\
\text { - рівень соціалізації; } \\
\text { - рівень державного втручання та ін. }\end{array}$ \\
\hline
\end{tabular}

У випадку, коли у територіальній обмеженості (локальності) домінує національна специфіка, така соціально-економічна система схильна до самовідтворення національної самодостатності та ідентичності, що робить їі менш залежною від глобальних тенденцій. Особливу роль у забезпеченні існування та упорядкованому функціонуванні національної соціально-економічної системи відіграє держава. Як політична форма організації суспільства вона втілює у собі суспільні інтереси (в ідеальному випадку), забезпечує безпеку суспільства та усіх його членів, створює умови до збереження територіальної цілісності та культурно-історичної індивідуальності. 
Отже, національна економіка (у контексті нашого дослідження) ідентифікується як державно-політичне утворення, що локалізоване в історичних, географічних, етнічних, політичних та економічних межах.

Визначальна роль держави знаходить свій прояв і через таку форму усуспільнення, як перехід у державну власність продуктивних сил, природних ресурсів та елементів власності на робочу силу. В умовах превалювання ринкового типу господарства державне усуспільнення більш за все пов'язується 3 формуванням державної монополії на управління та регулювання процесів суспільного відтворення. Держава відіграє діалектичну роль у забезпеченні цілісного існування національної економіки ринкового типу: самостійність та обмежена свобода економічних агентів $є$ базовою умовою суспільного відтворення, але стабільність цього процесу та мінімізація негативних зовнішніх ефектів неможлива без державної координації споживачів та виробників. Ще один аспект - це фінансова роль держави, що у першому наближенні peaлізується через розподіл значної частки національного доходу через державний бюджет. Значна роль держави знаходить свій прояв i через специфічну властивість соціалізації: урахування та узгодження інтересів економічних агентів, соціальних груп та суспільних об'єднань при формуванні та реалізації загальнодержавної стратегії соціально-економічного розвитку.

Висновки та перспективи подальших досліджень. Результати узагальнення теоретичних положень щодо сутності та змісту дефініцій «соціально-економічна система» та «національна економіка» обумовили висновок щодо неможливості розгляду економічної підсистеми (національної економіки) окремо від інших підсистем. Доведена доцільності та достатність використання дефініції «національна соціально-економічна система» як більш придатної для розв'язання діалектичної єдності соціальної та економічної підсистем суспільства. Отримані результати забезпечують методологічне підгрунтя для формування співвідношень відповідності дескрипторів національної соціально-економічної системи відповідним аксіоматичним умовам та базовим компонентам. Дуалістичне розуміння людини як економічного та інституційного базового елементу соціально-економічної системи $є$ цілком доцільним та придатним до розуміння сутності національної економки. Інститути, у свою чергу, слід розглядати як структуру зв'язків, що поєднують елементи у єдину цілісність. Доведено, що держава та ії інститути відіграють діалектичну роль у забезпеченні цілісного існування національної соціальноекономічної системи ринкового типу: самостійність та обмежена свобода економічних агентів $є$ базовою умовою суспільного відтворення, але стабільність цього процесу та мінімізація негативних зовнішніх ефектів неможлива без державної координації споживачів та виробників.

\section{Література}

1. Бурлуцька С. В. Системний підхід до управління проектами. Часопис економічних реформ. 2020. № 3 (39). С. 11-19.

2. Бурлуцька С. В. Стратегія забезпечення пружності сталого розвитку начіональної економіки: теорія та практика: монографія. Наук. ред. Н. Ю. Рекова. Дніпро: Середняк Т. К., 2016. 320 с.

3. Карнаи Я. Дефицит. Москва: Наука, 1990. 607 c.

4. Семашко Л. М. Сферный подход: Философия, демократия, рынок, человек. Москва: Нотабене, 1992. 368 с..

5. Башнянин Г. І. Товарні економічні системи і становлення ринкових структур. Економічні системи: монографія. Т. 2. За ред. проф. Г. І. Башнянина. Львів: ЛКА, 2011. C. $22-71$.

6. Ольсевич Ю. Я. Влияние хозяйственных реформ в России и КНР на экономическую мысль Запада. Москва: Мысль. 2007. 372 с.

7. Алиев А., Веснин В., Воловиков С. Системность национальной экономики и задачи ее государственного регулирования. Бизнес в законе. 2013. №6. С. 230-234.

8. Иода Ю. Влияние государственных экономических интересов на процесс самоутверждения национальной экономики. Сочиально-экономические явления и прочессы. 2011. №10. C. 75-83.

9. Залозная Г. М. Сущность национально-государственных экономических систем. Вестник ОГУ. 2004. №8. С. 28-34.

10. Дементьев В. Теория национальной экономики и мезоэкономическая теория. Российский экономический журнал. 2002. № 4. С. 71-78.

11. Білоцерківець В. В. Начіональна економіка: навч. посіб. для студ. вищ. навч. закл. 
За ред. В. М. Тарасевича Київ: Центр учбової літератури. 2009. - 280 с.

12. Національна економіка: навч. посібник / за заг. ред. В. П. Решетило. Харків: ХНАМГ. 2009. $386 \mathrm{c}$.

13. Поланьи К. Саморегулирующийся рынок и фиктивные товары: труд, земля и деньги. THESIS. 1993. Вып. 2, Т. 1. С. 10-17.

14. Автономов В. Модель человека в экономической науке. Санкт-Петербург: Экономическая школа, 1998. 230 с.

15. Hoто institutius - Человек институичиональный: монография. Под ред. О. В. Иншакова. Волгоград: изд-во ВолГУ, 2005. $854 \mathrm{c}$.

\section{References}

1. Burlutska, S. V. (2020) Systemic Approach to Project Management. Time description of Economic Reforms, 3 (39), 11-19.

2. Burlutska, S. V. (2016) Strategy for ensuring the resilience of sustainable development of the national economy: Theory and Practice: a monograph. Scientific editor N. Y. Rekova. Dnipro: Serednyak T. K, 320. Nauka, 607.

3. Karnai, J. (1990) Deficit. Moscow:

4. Semashko, L. M. (1992) Sphere Approach: Philosophy, Democracy, Market, Man. Moscow: Notabene, 368.

5. Bashnyanin, G. I. (2011) Commodity Economic Systems and the Formation of Market Structures. Economical Systems: Monograph. T. 2. Edited by Prof. G. I. Bashnyanin. Lviv: LCA, 22-71.

Стаття надійшла до редакції : 20.09.2021 p.
6. Olsevich, Y. Я. (2007) Influence of Economic Reforms in Russia and China on the Economic Thought of the West. Moscow: Mysl. 372.

7. Aliev, A., Vesnin, V., Volovikov, S. (2013). Systemic nature of the national economy and the tasks of its state regulation. Business in the law, 6, 230-234.

8. Ioda, Y. (2011) The influence of state economic interests on the process of selfassertion of the national economy. Socioeconomic phenomena and processes, 10, 75-83.

9. Zaloznaya, G. M. (2004) The essence of national-state economic systems. Vestnik $O G U, 8$, 28-34.

10. Dementiev, V. (2002) The theory of national economy and mesoeconomic theory. Russian economic journal, 4, 71-78.

11. Bilotserkivets, V. V. (2009) National Economy: Tutorial for Students of Higher Education. Ed. by V. Tarasiewicz Kyiv: Center of academic literature, 280.

12. National Economy: Tutorial (2009). Ed. by V. P. Reshetilo. P. Reshetilo. Kharkiv: HNAMG, 386.

13. Polanyi, K. (1993). The self-regulating market and fictitious goods: labor, land and money. THESIS, 2(1), 10-17.

14. Avtonomov, V. (1998) The human model in economic science. Sanct-Peterburg: Ekonomicheskaya shkola, 230.

15. Homo institutius - An Institutional Man (2005). a Monograph. Ed. by O. V. Inshakov. Volgograd: Volgograd State University Press, 854.

Стаття прийнята
до друку: $30.12 .2021 \mathrm{p}$.

\section{Бібліографічний опис для цитування :}

Бурлуцька С. В. Методологічні підгрунтя ідентифікації дескрипторів та контурів управління соціально-економічних систем / С. В. Бурлуцька, С. В. Бурлуцький // Часопис економічних peформ. - 2021. - № 4 (44). - С. 92-99. 